\title{
Double Segmental/Trifocal Ulnar Fracture with Ipsilateral Proximal Radial Butterfly Fracture Segment - A Rare Forearm Injury
}

\author{
Syam S Kumara, Vipin V Pillai ${ }^{a}$, Joji Krishnan ${ }^{a}$ \\ a. Department of Orthopaedics, Government Medical College, Thiruvananthapuram, Kerala, India
}

Published on $1^{\text {st }}$ June 2020

\begin{abstract}
Segmental forearm fractures are rare injuries in adults. ${ }^{1}$ Double segmental fractures/trifocal fractures are extremely rare, ${ }^{2}$ and guidelines regarding their management options are lacking in literature. We hereby report a rare case of a double segmental ulnar fracture (segmental ulnar shaft fracture with a concomitant communited olecranon fracture) with ipsilateral butterfly segment fracture of the radius. We used interfragmentary screws and 3.5 olecranon locking plate for proximal ulna and 3.5 DCP for distal ulnar fracture \& radial fracture. Perusal of literature showed a single case report, which suggested intramedullary nailing for radius and ulna, along with tension band wiring for olecranon. ${ }^{3}$ Here we present the outcome in terms of union, grip strength and Range of motion.
\end{abstract}

Key Words: Forearm Fracture, Radius, Double Segmental Fracture, Trifocal Fracture Ulna

\section{INTRODUCTION}

$\mathrm{B}$ oth bone fractures of forearm are extremely common, ${ }^{4}$ and internal fixation with plates is the most preferred treatment option..$^{5}$ As the whole of forearm is considered as an articular unit, stable anatomical reduction is mandatory in these type of fractures aiming at primary bone healing. ${ }^{6}$ However in comminuted and segmental fractures, biological fixation by a bridge plate or intramedullary nail may be preferred. ${ }^{7}$

Segmental forearm fractures are rare with $0.1 \%$ incidence $^{1}$ of all fractures in which either the radius or ulna alone or both together are fractured into more than two segments. As they are infrequent there are still dilemmas regarding the management options like whether to opt for bridge plates or intramedullary nail. Most studies are in support of bridge plating whereas intramedullary nails are reserved in case of soft tissue compromise. ${ }^{8}$

In a case of Double segmental (trifocal) ulnar fracture with ipsilateral radial shaft fracture, to the best of our knowledge, only a single study is reported in literature. Hence treatment guidelines are not well described. In the only case reported in literature, radial and ulnar fractures were treated by intramedullary nailing and the olecranon fracture addressed by tension band wiring. ${ }^{3}$

\section{CASE PRESENTATION}

34 year old gentleman presented to the emergency room after a road traffic accident with complaints of pain, swelling and deformity of right elbow and forearm. He was diagnosed to have proximal radius fracture with a butterfly segment, with ipsilateral double segmental ulna fracture (including comminuted fracture of olecranon) (AO/OTA 2R2A3 2U2C2). ${ }^{9}$ No signs of head, chest or abdominal injuries were present. There were no neurovascular deficits or signs of compartment syndrome.

\section{MANAGEMENT}

Patient's forearm was splinted, pre operative workup done, and was taken to the operation theatre Patient was positioned supine. Henrys approach for radius was used and radius was plated using 3.5 dynamic compression plate. Radius was chosen to fix initially as the ulnar side

Cite this article as: Kumar SS, Pillai VV, Krishnan J. Double Segmental/Trifocal Ulnar Fracture with Ipsilateral Proximal Radial Butterfly Fracture Segment - A Rare Forearm Injury. KJOrth. 2020 Jun 1;33(01):27-9.

Access this Article Online

$$
\text { Scan this QR Code }
$$

https://doi.org/10.52314/kjo.2020.v33i01.12 

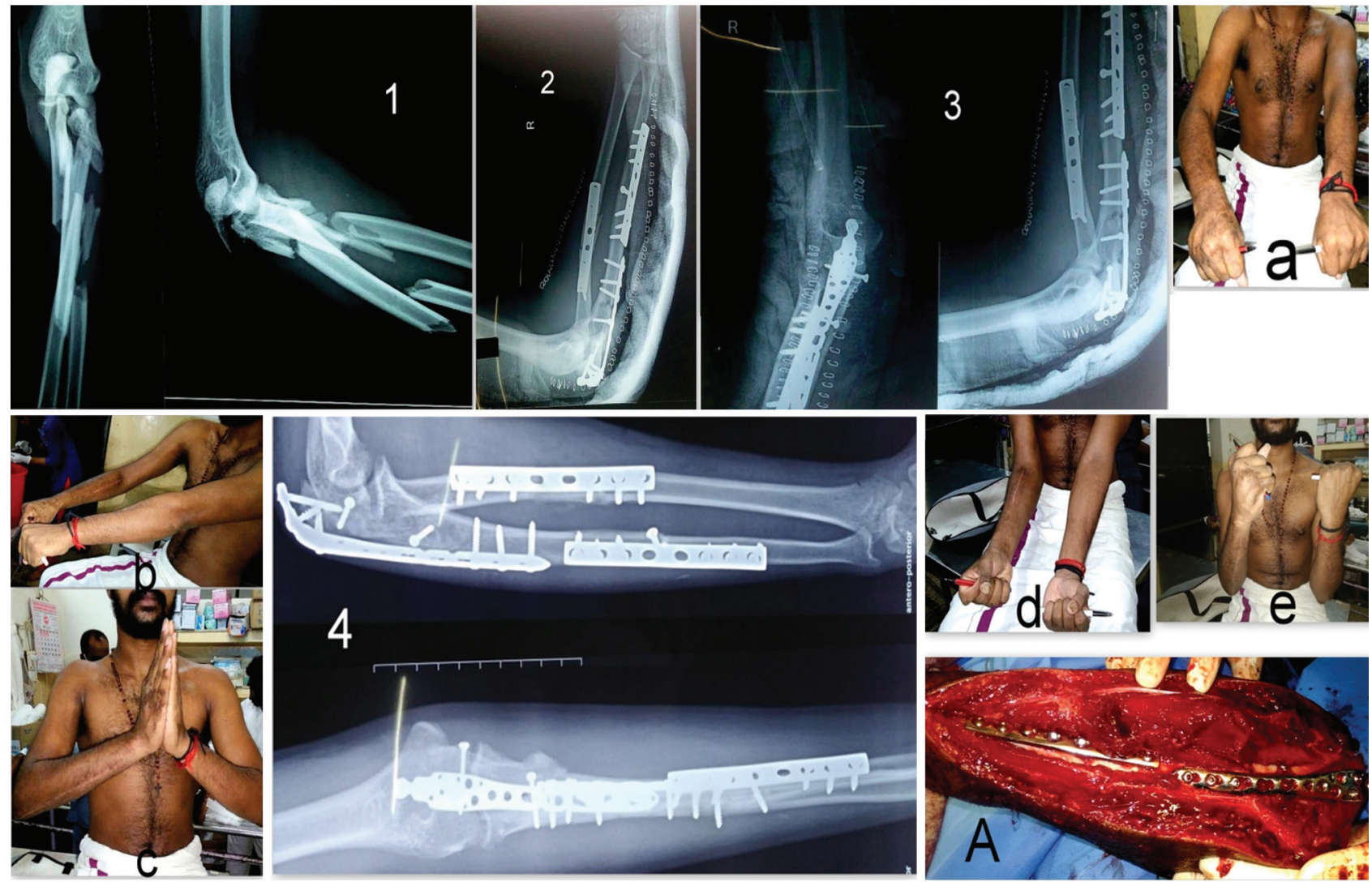

Figure 1. Showing clinical \& radiological findings. [a,b,c,d,e - Clinical photographs at 3 months followup visit;

1- Initial x-ray; 2\&3 - Immediate post op x ray; 4 - x ray at 3 months A - Intra op photograph]

was found to be more communited. Posterior approach to elbow was combined with Henrys approach for ulna. Olecranon fracture was fixed anatomically with interfragmentary screws and 3.5 olecranon locking plate. The plate chosen was a little longer so that it could achieve purchase on the middle fragment of ulna and thus cover the proximal fracture of ulna. Then the remaining ulnar fracture was fixed with 3.5 dynamic compression plate. Throughout the surgery, utmost care was given during soft tissue dissection to prevent devascularisation of bony fragments by respecting the periosteum and neighbouring tissues.

Postoperatively the patient was put on long arm splint and antibiotics were given for 1 week. No neurovascular complications or any signs of infection were present. Sutures were removed after two weeks and range of movements started after 3 weeks. Patient was followed up after 6 weeks and after completion of 3 months. Initially at the $6^{\text {th }}$ week patient was found to be having a little difficulty in flexion of elbow and supination of forearm, both of which improved at the 3 month followup. X-rays showed fracture union. The movements of elbow assessed and were of full range. Pronation was $90^{\circ}$, supination was $70^{\circ}$ and grip strength was fairly good (Figure 1). Patient underwent physiotherapy \& occupational therapy for functional improvement and was asked to start all his daily activities since then.

\section{DISCUSSION}

AO/OTA 2R2A3 2U2C2 ${ }^{9}$ fractures, apart from being segmental, are complicated by associated communition and extensive soft tissue damage. As they are somewhat trickier injuries to tackle, meticulous planning and surgical caution has to be exercised, taking the soft tissue damage and fragment communition into account. Literature suggests the use of plates for anatomical reduction, radial bow maintenance and rotational stability, whereas nails are better in severe communition and in soft tissue compromise. Hence, in our case, as we have to start early mobilization and as our soft tissue condition was favourable, we used dynamic compression plates for radius. However, in the similar case report by Kim MS etal, ${ }^{2}$ intramedullary nails were used for both the radius and ulna.

Proximal ulnar fractures comprise about $10 \%$ of fractures around elbow. ${ }^{10}$ They comprise a broad spectrum of fracture types and almost all are intraarticular, requiring anatomical reduction and early mobilization ${ }^{11}$ for a good outcome. Simple olecranon fractures without communition or instability are better treated by Tension band wiring ${ }^{12}$ and those which are comminuted and are associated with elbow instability are treated plate fixation. That was the rationale of using an anatomical olecranon locking plate in our comminuted olecranon fracture, in contrast to Kim etal ${ }^{3}$ who used tension band wiring as the olecranon fracture was simple. 


\section{CONCLUSION}

Double segmental/trifocal ulnar fracture with ipsilateral proximal radial fracture (AO/OTA 2R2A3 2U2C2) is an extremely rare injury. In similar injuries with communition of olecranon fragment, we recommend use of olecranon plating, along with 3.5 DCP's for radial \& ulnar shaft fractures giving extreme care to soft tissue dissection intraoperatively. Early mobilization along with physical medicine support and occupational therapy is recommended for full functional recovery.

\section{END NOTE}

\section{Author Information}

1. Dr Syam S Kumar, Senior Resident Department of Orthopaedics, Government Medical College, Thiruvananthapuram, Kerala, India

2. Dr Vipin V Pillai, Assistant Professor Department of Orthopaedics, Government Medical College, Thiruvananthapuram, Kerala, India

3. Dr Joji Krishnan, Assistant Professor, Department of Orthopaedics, Government Medical College, Thiruvananthapuram, Kerala, India

Conflict of Interest: None declared

\section{REFERENCES}

1. Thirunarayanan V, Ramprasath DR, Rajan A. Segmental Fractures of the Forearm-Outcome Analysis of Various Management Strategies. 2015 Feb; 14 (11):13-16
2. Ibrahim M, Cwilewicz J, Khan OH, Gibbon A. Unilateral, trifocal, diaphyseal fracture of the radius with ipsilateral mid-shaft ulna fracture in an adult: a case report. J Med Case Rep. 2011 Mar 29;5:123.

3. Kim MS, Moon KP, Cho HJ, Bae JY, Suh KT. Treatment of a Segmental Ulnar Shaft Fracture and an Olecranon Fracture. J Korean Orthop Assoc. 2010;45(6):496.

4. Raducha JE. Radius and Ulnar Shaft Fractures. In: Eltorai AEM, Eberson CP, Daniels AH, editors. Essential Orthopedic Review: Questions and Answers for Senior Medical Students [Internet]. Cham: Springer International Publishing; 2018 [cited 2021 Feb 4]. p. 61-2.

5. Al-Sadek TA, Niklev D, Al-Sadek A. Diaphyseal Fractures of the Forearm in Adults, Plating Or Intramedullary Nailing Is a Better Option for the Treatment? Open Access Maced J Med Sci. 2016 Dec 15;4(4):670-3.

6. Egol KA, Kubiak EN, Fulkerson E, Kummer FJ, Koval KJ. Biomechanics of locked plates and screws. J Orthop Trauma. 2004 Sep;18(8):488-93.

7. Stuermer EK, Sehmisch S, Frosch K-H, Rack T, Dumont C, Tezval $\mathrm{M}$, et al. The Elastic Bridge Plating of the Forearm Fracture: A ProspectiveStudy. EurJTraumaEmerg Surg. 2009Apr;35(2):147-52.

8. Gao H, Luo C-F, Zhang C-Q, Shi H-P, Fan C-Y, Zen B-F. Internal fixation of diaphyseal fractures of the forearm by interlocking intramedullary nail: short-term results in eighteen patients. J Orthop Trauma. 2005 Jul;19(6):384-91.

9. Multifragmentary ulnar fracture with non-multifragmentary radial fracture [Internet]. [cited 2021 Feb 4].

10. Siebenlist S, Buchholz A, Braun KF. Fractures of the proximal ulna: current concepts in surgical management. EFORT Open Rev. 2019 Jan;4(1):1-9.

11. Azar FM, Beaty JH, Canale ST. Campbell's operative orthopaedics. 13th ed. Philadelphia: Elsevier, 2017, Chapter 57. Fractures of the shoulder, arm and forearm p2927-3004

12. Powell AJ, Farhan-Alanie OM, Bryceland JK, Nunn T. The treatment of olecranon fractures in adults. Musculoskelet Surg. 2017 Apr;101(1):1-9. 